\title{
消化器内視鏡の新しいデバイスの開発とその考え方 〜低侵襲治療時代に扮けるストラテジー〜
}

久米 恵一郎

産業医科大学 医学部 第3内科学

要旨：内視鏡医療に代表される低侵襲治療は,各々の方法の意図通りに成功すれば, 患者には低侵襲で終わるが,この結果を担保する医療側の負担は過大になりつ つある，進みゆく低侵襲治療時代の入口戦略として, 臨床医学の場へ提供すべ き治療法やデバイスの評価基準の必要性を感じていた，今回, 独自の判断基準 による筆者の取り組みを紹介した。

キーワード：新しいデバイス, 消化器内視鏡, 低侵襲治療.

（2010年 8 月12日 受付, 2010年10月28日 受理）

は じめに

先端医療の眼目の一つである治療の低侵襲 化は,その治療を意図通り完遂できれば,確か に患者への侵襲は低くなる。しかし，これを 実現するために医療側に求められる技術は, 逆説的に高度化・高負担化が進んでいる。内 視鏡治療の対象疾患は, 元来外科開腹手術に より視野を大きくとれば直視下に安全に治療 できるが,低侵襲治療の内視鏡治療では, 特有 の合併症により,死亡例を含め, 当初より開腹 手術を選択した場合より患者に過大な負担が かかることもしばしばある。ここに本来の内 視鏡治療の利点を担保し, 手技の平準化·容易 化·安全化がより求められる時代背景がある。

筆者は，各分野に広がる内視鏡診療のうち 消化器内視鏡を專門として,これまで「手技の 容易化と安全化·普遍化」をコンセプトに15の 消化器内視鏡の新しい機器や治療法の開発を
してきた，日常の内視鏡診療の中で, 誰もが 共通に遭遇する困難克服の視点で開発を始 め, 若手内視鏡医の指導の中で, 彼らの手技過 程で律速段階となる過程の容易化の観点での 開発に移行し, 現在は次世代の普遍的な内視 鏡医療を念頭にロボット内視鏡の開発に取り 組んでいる。しかしながら, 新しいデバイス の開発は, 解決すべき課題に焦点が集中し過 ぎて独善的になりがちである。 また, そうで なくとも新たな任組みを取り入れれば，必ず メリットと共にデメリットが発生する。従っ て, 既存の治療法の到達点や安全性を担保し た上で, 新しいデバイスによるメリットがデ メリットを上回ることが, 臨床応用の上で必 須の条件である、筆者が着想したデバイスを どのように取り扱うべきか, 即ち, アイディ アとして引き出しにしまっておくべきか, 臨 床応用すべきか, 普遍性があって製品化を依 頼すべきかを検討するための，独自のフロー 
チヤートを作成した(Fig. 1).今回，これまで に筆者が開発した15のデバイスにつきこの フローチャートに添って解説古る(Table 1).
なお，新規デバイスの臨床応用の際には倫 理委員会の承認と個々にインフォームドコン セントを行って実施した。

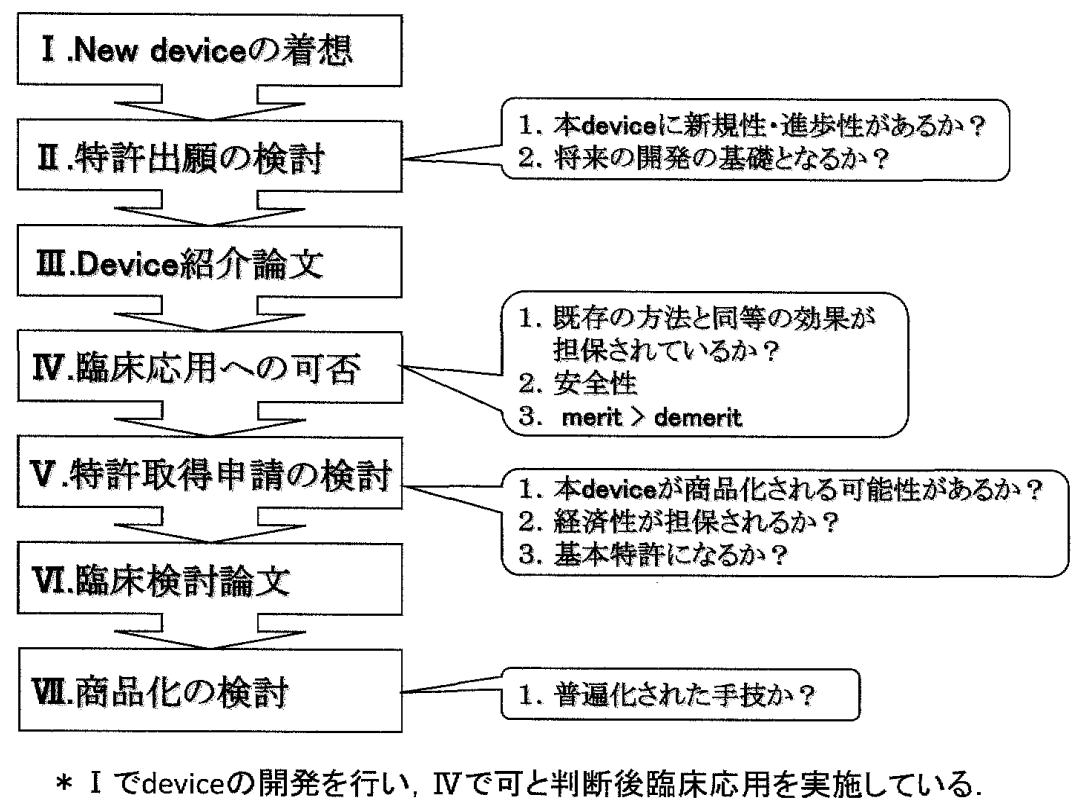

Fig. 1. Development and evaluation of new devices.

Table 1. Results of evaluation with new devices for Fig. 1

\begin{tabular}{|c|c|c|c|c|c|c|}
\hline I & II & III & $\mathrm{N}$ & $\mathrm{V}$ & $\mathrm{VI}$ & VII \\
\hline 洗浄機能付き内視鏡フード (Type 1) & O & $\rightarrow$ & 0 & 0 & 0 & $\bigcirc$ \\
\hline 洗浄穖能付き内視鏡フード (Type 2) & O & $\rightarrow$ & O & O & $\bigcirc$ & $\bigcirc$ \\
\hline 洗浄機能付きEMRCフード & $\rightarrow$ & $\rightarrow$ & O & $\rightarrow$ & 0 & \\
\hline 2チャンネルEMRCフード & $\rightarrow$ & $\rightarrow$ & O & $\rightarrow$ & O & \\
\hline スネア留置型EMRCフード & $\rightarrow$ & $\rightarrow$ & O & $\rightarrow$ & 0 & \\
\hline 外部CCDカメラ補助下EMRC-C法 & $\rightarrow$ & O & & & & \\
\hline マルチカメラシステム & O & O & & & & \\
\hline 振動機能付きEAMフード & O & $\bigcirc$ & & & & \\
\hline フード型ESDナイフ & O & O & O & O & O & \\
\hline ワイパーナイフ & O & 0 & & & & \\
\hline 高粘稠物質を用いたESD & O & $\bigcirc$ & $\triangle$ & & & \\
\hline 凝固洗浄機能付き先端アタッチメント & $\rightarrow$ & $\rightarrow$ & O & $\rightarrow$ & O & \\
\hline 振動機能付き内視鏡 & 0 & 0 & & & & \\
\hline 内視鏡用ファンデバイス & $\rightarrow$ & 0 & & & & \\
\hline マイクロロボット型自走式大腸内視鏡 & & & & & & \\
\hline
\end{tabular}

$\bigcirc:$ 実施済, $\triangle$ : 実施中, $\rightarrow$ : 実施せず (通過), 無印 : 未実施, I - VIIは,Fig. 1のステージに対応 EMRC: endoscopic mucosal resection using cap, EMRC-C: EMRC and closure, CCD: charge coupled device, ESD: endoscopic submucosal dissection 
フローチャートによる開発デバイスの分析と解説

1. 洗浄機能付き内視鏡フードに関する開発 (2件)

1) 洗浄機能付き内視鏡フード (Type 1) (Fig. 2)

I. 着想・背景：汎用内視鏡は通常 1 チャンネ ル(一つの鉜子孔)であるため,このチャンネ ルに処置具を挿入しながら実施する内視鏡治 療中に, 出血などによる視野の不良が出現し 治療の続行が不可能になった場合, 挿入中の 処置具を一度抜去して，洗浄水を入れたシリ ンジをチャンネルに挿入して視野を洗浄し， 再度処置具を挿入して治療を再開することに なる. 特に消化管出血時にクリップなどの止 血処置具を挿入後視野不良となると, 何らの 処置をしない時点で処置具とシリンジの抜き 差しを繰り返すことになる。そこで, 使用中 の処置具を拔去しなくとも視野の洗浄を可能 にするため, 内視鏡の先端に装着するフード に洗浄機能を取り付けることを着想した。

II. 特許出願：内視鏡スコープの本体に洗浄 機能が搭載されたウォータージェット内視鏡 は未発表であり, 新規性・進歩性いずれもある と考え出願した $[1]$.

III.デバイス紹介論文：執筆せず.

IV. 臨床応用：通常使用する先端フードに よる負荷と汎用されているEVL (endoscopic variceal ligation) deviceの負荷を勘案し, 動物 実験などの前検討なく, 臨床応用することに 特段の問題なしと判断した。

$\mathrm{V}$. 特許申請 : 普遍化される可能性と将来複 杂倠化する内視鏡治療に洗浄機能は必須と考え 申請した。審査中, ウォータージェット内視 鏡の商品化, また, 内視鏡メーカーの各種特許 などに此し, 新規性・進歩性ないと判断され, 拒絶查定となった。これに対して。汎用内視 鏡の先端に取り付ければ, 高価なウォーター ジェット内視鏡を購入しなくとも, 安価に同 等の機能が獲得できるという経済性に進歩性 があると審判請求(不服2005-15955) し, 主張 が認められ逆転査定となった [1].
VI. 臨床検討論文：15例の消化管出血患者を 対象とした。 まず, 出血点の発見目的でフー ドを装着せず内視鏡を挿入し, 発見後, スコー プを一度抜去して, 自作洗浄機能付きフード を装着後，出血点を洗浄しながら主にクリッ プ止血を実施し，全例成功した．平均手技時 間16.6分であった[2]。

VII. 商品化の検討 : この検討で試作に使用し たフードは, フード長11 mmのプラスチックフー ドであったが, その後, 胃角部小彎の出血性潰 痬を見上げで処置する際，フード内に血液が 貯留してフードを拔去しなければならなくなっ たという弱点を露呈し, 次の開発となった。

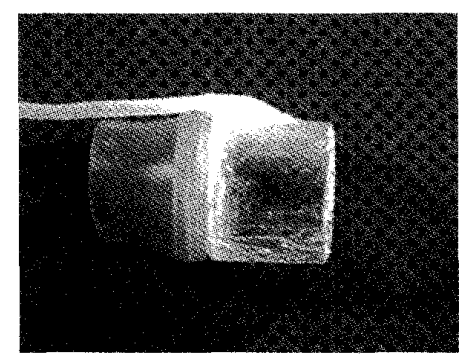

Fig. 2. Irrigation hood (type 1).

2) 洗浄機能付き内視鏡フード (Type 2) (Figs. 3, 4) I . 着想・背景：洗浄機能付き内視鏡フード (Type 1) が露呈した弱点を克服するため, 力 ウンタートラクションなどのフード機能を残 しつつも, 血液のフード内貯留を防止する目 的で,フードをカットすることを着想し, 周 在性が3分の1のカッティングフードによる Type 2を開発した。

II. 特許出願 $\sim V$. 特許申請: 洗浄機能付き 内視鏡フード (Type 1)に同じ.

VI. 臨床検討論文：18例の消化管出血患者を 対象として, 最初から Type 2洗浄機能付きフー ドを装着し，出血点を洗浄しながら主にク リップ止血を実施，全例成功した。平均手技 時間11.8分であった[3]。

VII. 商品化の検討：Type 2フードは, 若手内 視鏡医より挿入時にリスクを感じると指摘 され，また，菲溥化した潰瘍底を穿孔させる リスクなどを想定して, Type 1,2を踏まえて 
商品化へ向けて改良した。最終的にフード 長 $4 \mathrm{~mm}$ の先端アタッチメントによる試作品 が双方の問題点を克服していると判断した. これを基にクリエートメディック社により 4 度の試作改良が繰り返され，同社と独占契約 を結び製品化された (Fig. 4). 特許と英論文, プロタイプの自作の3 点セットを基に, 製品 名は洗浄用内視鏡フード (Type KUME) とな り，2006年 4月20日に上部消化管用（サイズ； $9,10 \mathrm{~mm})$ が, 2008年7月 1 日下部消化管用(サ イズ；11.5, 12.5 mm）方発売, 2006年1393本, 2007 年1388本, 2008年1514本, 2009年1524本 (メーカー報告) が販売された。

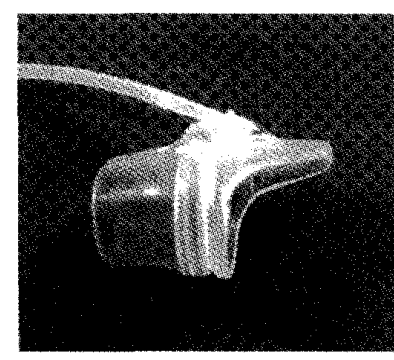

Fig. 3. Irrigation hood (type 2).

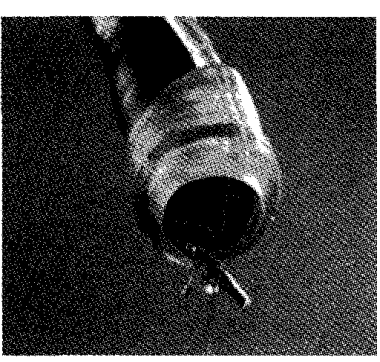

Fig. 4. Irrigation hood (Type KUME).
2. 内視鏡的粘膜切除術 $(E M R)$ に関する開発 (6件)

1) 洗浄機能付きEMRCフード (Fig. 5)

I. 着想・背景 : EMR (endoscopic mucosal resection)のうち, 最も容易な手技は, キャッ プイフドを用いた吸引法によるEMRC (EMR using cap) やEAM (endoscpic mucosectomy) と 考えていたが, 唯一の矢点は吸引が盲目的で 必ずしも病変の中心を吸引できないセンタリ ングに関連するものと考えていた，EMRCの キャップを用いたEMRでは，チャンネルに挿 入したスネアを予めプレループする必要があ るため,プレループ後チャンネルは使用でき ない。一度で所望の吸引をできずに吸引を中 止すると病変部が湧出性出血をして, 今度は 正確な病変の認識ができなくなるので。プレ ループ状態で繰り返し吸引しても病変部を洗 浄できるように, EMRCフードに洗浄チュー
ブを取り付けた。

II. 特許出願：洗浄機能付き内視鏡フードと 同様の意図と構造をもつので出願せず.

III.デバイス紹介論文：執筆せず。

IV. 臨床応用：既存のEMRCフードに洗浄 チューブを接着することで新たな障害を発生 させる可能性は極めて低いと判断した。

$\mathrm{V}$. 特許申請：未出願

VI. 臨床検討論文：15名のガイドライン内の 早期胃癌患者を対象として, 卒後 3-6年目の 若手内視鏡医 5 名を中心に施行した。一括切 除率: $86.7 \%$, 平均切除切片 : $22.3 \mathrm{~mm}$, 平均 施行時間：19.3分であった[4]。

VII. 商品化の検討：吸引を繰り返すと診断に 影響はなかったものの病変が損傷することも あり，普遍性には問題点を残すと判断した。

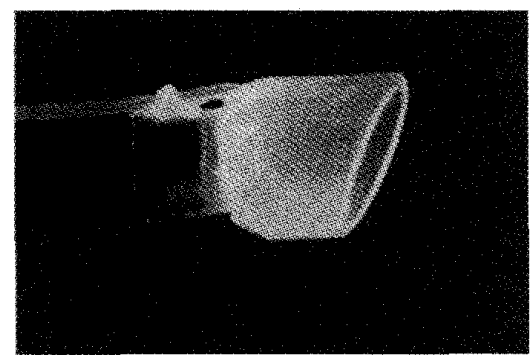

Fig. 5. Irrigation prelooped hood.

2) 2チャンネルEMRCフード (Fig. 6)

I . 着想・背景：洗浄機能付きEMRCフード では, 繰り返しの吸引でセンタリングを達成 することを考えたが, 病変の損傷を免れない ため，一度の吸引でセンタリングを達成でき るように, スネア挿入のためのチャンネルを 外付けにしてフードに接着し, スコープ本体 のチャンネルには把持釷子を挿入, 病変の中 心を把持しながら吸引することを可能にする 2チャンネルEMRCフードを開発した。把持 鉜子操作時の視野不良を考え, 洗浄チューブ は残した。

II. 特許出願 $\sim V$. 特許申請 : 洗浄機能付き EMRCフードとほぼ同様. また,メーカーな どによる $[5]$ 外付けチャンネルに関する先行 特許多数あり. 
VI. 臨床検討論文：12名のガイドライン内の 早期胃癌患者を対象とし, 卒後 3-6年目の若 手内視鏡医 5 名を中心に施行した。一括切除 率 : $91.7 \%$, 平均切除切片 : $24.5 \mathrm{~mm}$, 平均施 行時間：19.0 分であった $[6]$.

VII. 商品化の検討：意外であったが把持針子 の操作にコツが必要で, 普遍性には問題点を 残すと判断した。

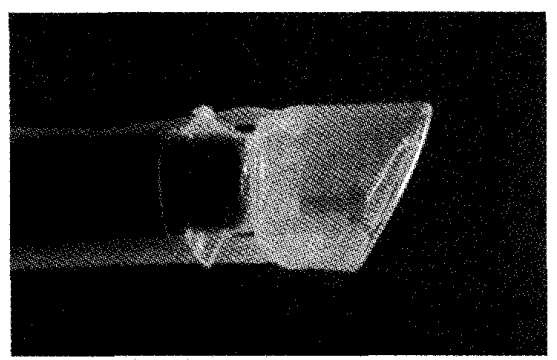

Fig. 6. 2-channel prelooped hood.

\section{3) スネア留置型EMRCフード (Fig. 7)}

I 。着想・背景：上記二つのフードではセン タリングを中心に考えたが, 若手内視鏡医が EMRCでもっとも户惑ったのがプレループ で, センタリングはやや犠牲にしても手技を 容易化·安定化することを優先して, 2チャン ネルEMRCフードで予めプレループしたス ネアをセロテープで3ヶ所固定することによ り, 手技中のプレループの手間を無くすこと を考え開発した。なお，洗浄チューブは接着 しなかった。

II. 特許出願 $\sim V$. 特許申請 : 上記二つとほ ほ同様.

V. 臨床検討論文：27名のガイドライン内の 早期胃癌患者を対象と, 卒後 3-6年目の若手 内視鏡医 7 名を中心に施行した。一括切除 率: $88.9 \%$, 平均切除切片 : $27.6 \mathrm{~mm}$, 平均施 行時間：15.8分であった[7].

VII. 商品化の検討：2チャンネルEMRCフー ドに比して一括切除率に遜色なく, 若手内視 鏡医にも好評で手技の容易化・普遍化を一定 水準達成したと判断し，この時点で究極の EMRと考え，製品化依頼をメーカーにした が、採算面などの理由で実現しなかった。

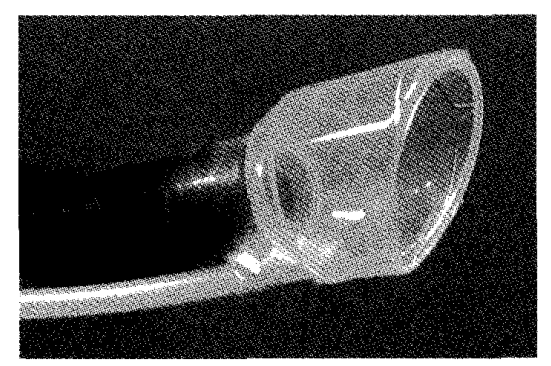

Fig. 7. Internally retained snare hood.

4) 外部CCD (Charge coupled device) カメラ補 助下EMRC-C (EMRC and closure) 法 (Fig. 8)

I . 着想・背景：EMR後に入院を要するのは, 切除後の潰瘍に基づく出血・穿孔のリスク観 察が主因であるが,この潰瘍を切除時に同時 に縫縮しとげると, 日帚り手術が可能になる と考え,この開発を着想した。、スネア留置 型EMRCフードの先端にさらに $3 \mathrm{~mm}$ 程度の フードを接合し，その新たなフード部分に留 置スネアを外側にプレループレたデバイスで ある。病変部含めた粘膜を最大吸引後, まず 外付けのCCDカメラで観察しながら留置ス ネアにより吸引最下部を確実に縫縮する。即 座に, 切除用のスネアでスネアリングし切除 することにより，切除と同時の縫縮を実現す ることを目的とした。

II. 特許出願：限定された手技となるので，こ のまま普遍化できるとは考えられず未出願。

III.デバイス紹介論文：切除豚胃にて仮想病 変 2 病変を切除, 平均 $15 \mathrm{~mm}$ の切片が切除でき た[8].

IV. 臨床応用：手技的には, 臨床に堪えうる 完成度があると判断し, $10 \mathrm{~mm}$ 以内の限定し た病変での臨床応用も考えた。しかし, 何ら かの理由で遺残がおこり, 特に遺残を切除時 に気付かず縫縮により深部浸潤を起こし粘 膜下腫演様の再発を来すような事態も想定さ れ，日帰り手術というフレーズには経営主義 的な面も否めず, 現状では臨床応用は倫理的 でないと判断した。

$\mathrm{V}$. 特許申請 $~ V I I$. 商品化の検討 : $\mathrm{V}$ 段階で 留保. 

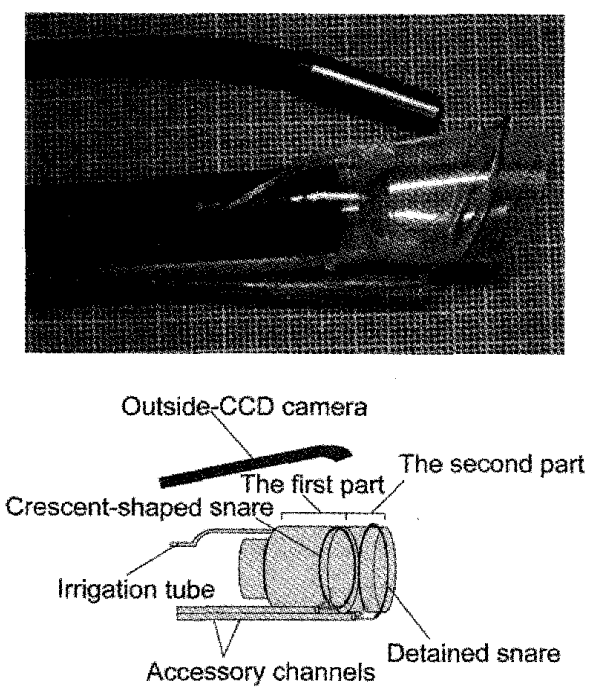

Fig. 8. Endoscopic aspiration mucosectomy and closure (EAMC). (Reproduced with permission from Wold Jornal of Gastrointestinal Endoscopy 1(1): 23 Fig. 4.)

5) マルチカメラシステム (Fig. 9) (平成17年 度内視鏡医学研究振興財団賞受賞)

I．着想・背景：通常, スコープ本体に備わる 単体のカメラのみにて内視鏡視野を得ている がこれでは必ずしも全貌を見通すことがで きないため, 処置・治療の一部が盲目的となり 術者の勘や経験に基づいて実施されるのが実 情である。実際，処置・治療法によりスコー プ本体の単体のカメラによる死角は様々で ある。この処置・治療時の死角が存在する部 位を適確に観察できるよう新たなカメラを 設置することにより死角をなくし，もしくは 少なくし，より安全な内視鏡による処置・治療 を可能にすることを考え，まず $20 \mathrm{~mm}$ 以上の 病変をstrip biopsy法で一括切除することを念 頭に, 局注された病変の近位側を汎用スコー プで観察しながらスネアを拡げ，一方，遠位側 をもう一つの側視鏡で観察しながら, 且つ, ス ネアの遠位端を掴み, スネアリング時に病変 の遠位端の上をスネアが滑らないように把持 して, 一括切除を目指す 1 チャンネルカメラ フードを開発した。

II. 特許出願：マルチカメラのあらゆる可能 性を考慮したコンセプト特許を出願した[9]。
IIIテデ゙イス紹介論文：先端フードに市販の 口腔内スコープを先端長の可変が可能な様に 接着し，さらに同スコープに外付けチャンネ ルも接着することで上記着想を実現した。切 除豚胃にて仮想病変 2 病変を切除, 平均 $30 \mathrm{~mm}$ の切片が切除できた[10].

IV. 臨床応用 : ESD (endoscopic submucosal dissection）を凌駕するメリットを提起できる 水準に達成しなかったので, 臨床応用には至 らなかった。

$\mathrm{V}$. 特許申請〜VII. 商品化の検討：IV段階で 留保. マルチカメラのコンセプトは今後の シーズとなると考えている。
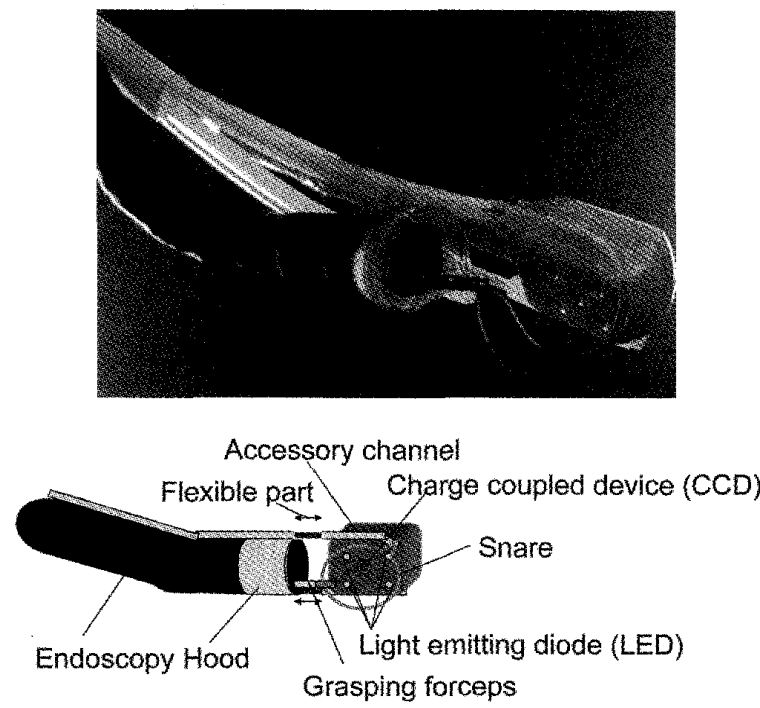

Fig. 9. Multi-camera system of the endoscopy using 1-channel camera-hood. (Reproduced with permission from Wold Jornal of Gastrointestinal Endoscopy 1(1): 24 Fig. 6.)

6) 振動機能付きEAM(endoscopic aspiration mucosectomy) フード (Fig. 10)

I 。着想・背景：吸引法によるEMRのもう一 つの問題点として全層吸引による穿孔のリス クがあり，経験則による加減したスネアリン グによりリスク軽減を図るが, 不確実な過程 でもある。そこで, スネアリング時にスネア のみに振動を加えて筋層・漿膜を振るい落と すような機序にて, 術者の手の加減によらな いスネアリングを可能にした振動機能付き EAMフードを開発した。 
II. 特許出願：後述する振動機能付き内視鏡 も含め, 内視鏡治療のあらゆる現場に「振動」 という第 3 の要素を導入することに関する出 願をした $[11,12]$.

III. デバイス紹介論文：クリエートメディッ ク社製の内視鏡フードを改造した。まず,フー ド (e)にL字型摇動部 $(\mathrm{g})$ が振動部以外に振動 が伝達しないように側孔を開ける。L字型摇 動部 $(\mathrm{g})$ には摇動部鉗子孔(h)があり,これは 外付けチューブの鋛子孔と直線的な同心を 維持するように開ける。 L字型摇動部 $(\mathrm{g})$ は, 振動を惹起する偏心モー夕(b)に固定さ れる.この振動部 $(b+g$ で構成)の振動が内視 鏡本体 (a)やフード (e), キャップ部 (f) 他に伝 達しないよう防止するため,ブチルゴムより なる振動減衰部 (c)により構成される振動吸 収部に振動部は密閉される。振動吸収部は, キャップ部(f)に固定する。これにより内視 鏡スコープ $(\mathrm{a})$ の外付けチャンネルと摇動部 鉗子孔(h)の双方に挿入された処置具のみに 振動が伝達され, 振動が追加された内視鏡的 な処置を可能とする. Figure 10に設計図と完 成品 (内視鏡に装着しスネアを拡張)を示す。 これを用いて, 切除豚胃を用いて同一条件下 で18の仮想病変を最大吸引して切除した。振
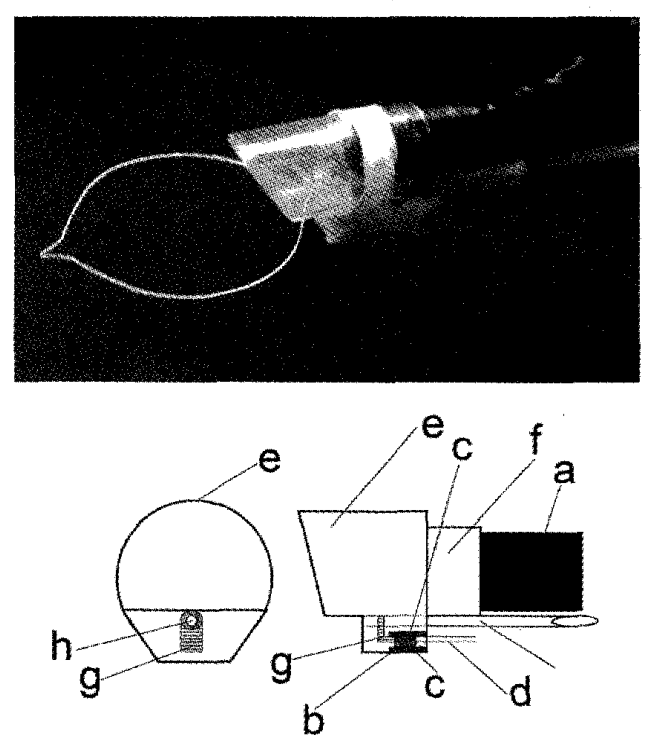

Fig. 10. Vibration hood. (Reproduced with permission from Wold Jornal of Gastrointestinal Endoscopy 1(1): 24 Fig. 5.)
動追加群 $(10,000 \mathrm{rpm})$ では全例穿孔せず, 無 振動群では2例穿孔した[13].

IV. 臨床応用：複雑な構造で, 臨床応用には 主に防水面に課題を残している。

$\mathrm{V}$. 特許申請 $~ V I I$. 商品化の検討 : IV段階で 留保.

3. 内視鏡的粘膜下層剥離術 (ESD) に関する 開発 (6件)

1) フード型ESDナイフ (Figs. 11, 12)

I. 着想・背景：2003年当時のESDの現状に対 するアンチテーゼを二つ着想した。一つは, 「外科医の左手」の役割となる把持・牽引機能 を追加して, 術野の安定性を高めることで達 成したいと考えた。 もう一つは, ナイフとス コープの操作自体を可能な限り単純化したい と考えた。前者は把持鉗子により可能だが, 外付けチャンネルを用いた機能追加は容易に 発想し得, 鉗子孔に挿入する夕イプのナイフ に手技の限界があると感じていたのでナイフ 自体に工夫を凝らした。具体的には, 洗浄機 能付き内視鏡フード (Type 2)の内側に弧状に スネアを固定することによりESD用のナイフ として開発した(Fig. 11a)。本ナイフによる 基本操作は, 単純な押し切りである。しかも, フードの外側を剥離面筋層側に位置させれ ば,ナイフ部は剥離面病変側を介してのみ通 電するため, 穿孔の危険は理論上ない. 洗浄 機能付きである。

II. 特許出願：ナイフ部にスネアを使用し, スネアの拡縮がそのままナイフ長の可変にな ることを踏まえて出願した[14]。

III. デバイス紹介論文：剥離面病変側を把持 鉗子で把持しながら, 視認下で押し切りする ことで, ESDが達成された(Fig. 11b)。切除豚 胃を用いて仮想病変 3 切片, 平均 $30 \mathrm{~mm}$ の切片 を平均3分で切除した[15].

IV. 臨床応用：安定した手技で切除效率もよ く、それまでとまったく発想の異なる点を考 慮しても臨床応用上特段の問題も無いと判断 し実施した。 
V. 特許申請：特許申請し, 拒絶理由通知に対 する回答が認められ特許查定となった[14].

VI. 臨床検討論文：7例の切除を実施した。 平均切除切片径 $43.7 \mathrm{~mm}$, 平均手技時間 77.1 分 であった[16]。

VII. 商品化の検討：クリエートメディック社 上り商品化のオファーがあり，これを受諾し て独占契約を結び商品化された。同社の薬事 関連の都合で, 最終的には市販のスネアを装 着するアタッチメントとして製品化された。
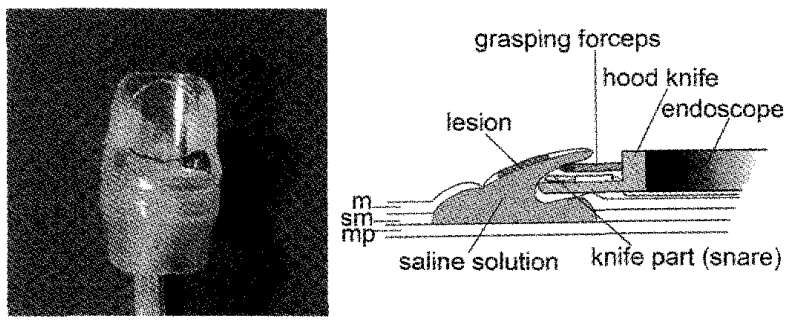

Fig. 11. Hood knife. (Reproduced with permission from Wold Jornal of Gastrointestinal Endoscopy 1(1): 26 Fig. 7.)

洗浄用内視鏡フード (Type KUME) と同様, 特 許と英論文, プロタイプの自作の3点セットを 基に, 製品名は洗浄用キャップナイフアタッ チメント(Type KUME) (Fig. 12：スネアを装 着した実施形態)となり，2006年6月30日に発 売開始された。利益相反をやや過剩に意識し て, 販売開始後学会などでの口頭発表を控え たこともあり，売り上げは，20本(メーカー報 告)に留まる。

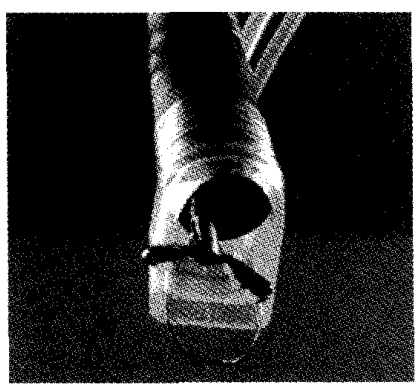

Fig. 12. Irrigation cap knife attachment (Type KUME).

2) ワイパーナイフ (Fig. 13)

I 。着想・背景：オリンパス社のR-scope (mul- tibending double-channel therapeutic endoscope) [17]に対するアンチテーゼとして着想した. フードナイフ Fig. 11)のスネアを針状ナイフ に置換し, 且つ,カッティングフード上を文字 通り自動車のワイパーの如く左右に摇動する ワイパーナイフ Fig.13a)を開発した。

II. 特許出願：上記背景より新規性はないと 判断した。

III. デバイス紹介論文：剥離面病変側を把持 鉜子で把持しながら, 視認下でワイパー様に作 動させることでESDが達成された(Fig. 13b). 切除豚胃を用いて仮想病変 3 切片, 平均 $30 \mathrm{~mm}$ の切片を切除した[18].

IV. 臨床応用 : メカニカルな剥離過程は興味 深いが,フードナイフの単純な押し切りに比 較して切除効率の低下が否めず, 且つ, 同ナイ フを凌駕するメリットを見出せなかったの で, 臨床応用に踏み切らなかった。但し, 後述 する経口的内視鏡遠隔操作システムの開発後 には, 臨床応用も考えている。

$\mathrm{V}$. 特許申請〜 VII. 商品化の検討：IV段階で 留保。
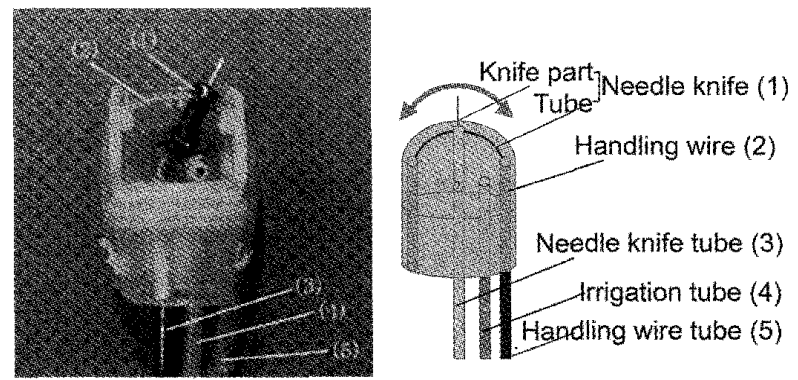

grasping foceps

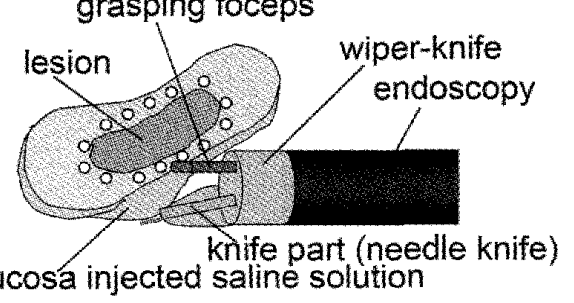

submucosa injected saline solution

Fig. 13. Wiper knife. (Reproduced with permission from Wold Jornal of Gastrointestinal Endoscopy 1(1): 27 Fig. 9.)

3）高粘稠物質を用いたESD (Fig. 14)

I。着想・背景：ESDでは剥離の手技がもっ 
とも熟練を要するが,この剥離を容易化する 目的で外科医が術中沉用する鈍的剥離をESD に導入することを着想した。当初粘膜下にバ ルーンカテーテルを挿入して実現しようとし たが所望する部位を必ずしも剥離できなかっ た。そこで, 高粘稠物質の局注のみにより鈍 的剥離を実現することを考え，開発した。

II. 特許出願：薬剤及び濃度の実験データを 得た後,出願した[19].

III．デバイス紹介論文：当初各種ゼリーの局 注を考えたが, 市販の穿刺針では口径が細く 注入できなかったため, 18 ゲージの穿刺針を 自作して局注に成功した。周辺切開のみによ り剥離が実現された[20]，次に，臨床応用を 前提にした安全性の高い物質による鈍的剥離 を実現するため, 外科手術中に癒着防止目的 で介在させるシートの成分であるカルボキシ メチルセルロースを選定し，至適濃度が $2.5 \%$ であることを明らかにした，全身麻酔下のミ 二豚にて実施したところ，完全鈍的剥離に成 功し, 同剂により剥離面が被覆され, その粘稠 度と重量により出血点は自然止血されていた (Fig. 14) [21].

IV. 臨床応用：上記結果を基に, 胃癌全摘胃 の正常粘膜部分でヒトに於いても鈍的剥離が 実現することを確認し臨床応用を開始した。 数例実施したが，最大でも全体の5割程度の 鈍的剥離に留まるため, 現在局注デバイスを 開発中(特許出願準備中)である.

$V$. 特許申請：現在，申請中である。

VI. 臨床検討論文：新デバイス導入後の良好 な治療成績が得られれば執筆する。

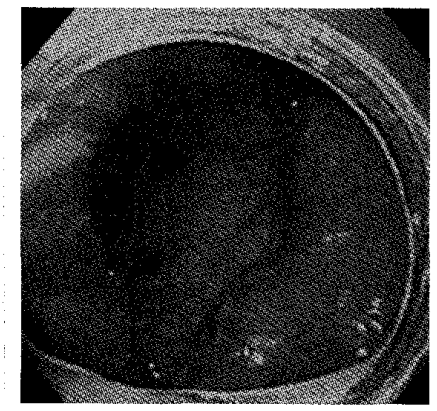

Fig. 14. ESD with blunt abrasion.
VII. 商品化の検討： 2 社と商談したが，ムコ アップ®(ヒアルロン酸ナトリウム)の市販化 もあって実現していない。

VIII. 追加 : この研究開発のみ助手 : 山崎雅広 の着想であり彼の学位論文となった。

4）凝固洗浄機能付き先端アタッチメント (Fig. 15)

I 。着想・背景：ESDには頻回の止血を要す るが, 止血鉗子を使用する場合, 汎用内視鏡で は挿入ナイフを一度抜去しなければならない ので, 止血と洗浄の二つの機能を先端アタッ チメントに追加することを着想した，総胆管 結石治療に使用するESTナイフの先端を切断 し, 長さを可変できるワイヤーと胆管造影用 のルーメンを得, ワイヤーの先端を丸めて凝 固錙子の役割を与え, 造影用ルーメンを洗浄 機能として用い, 先端アタッチメントに接着 して完成した（Fig. 15）。 また, 高周波電源装 置をESD用ナイフと本デバイスで共用するた め, 両者の尃用切り換えスイッチも合わせて 製作した。

II. 特許出願：手軽に製作できる点が最大の 長所であったので特許性はないと判断した。

III. デバイス紹介論文：執筆せず。

IV. 臨床応用：数例に使用したが, 凝固鉗子 の先端が止血部位に接着し, 剥がすと再出血 することもあり, 普遍性の点で問題が残った。 臨床応用のデバイス紹介として論文化した [22].

$\mathrm{V}$. 特許申請 VII. 商品化の検討：IV段階で 留保. 凝固鉲子の先端をコーティングすると 普遍性を獲得できると考えるが, マルチルー メンのオーバーチューブや先端フードなどの

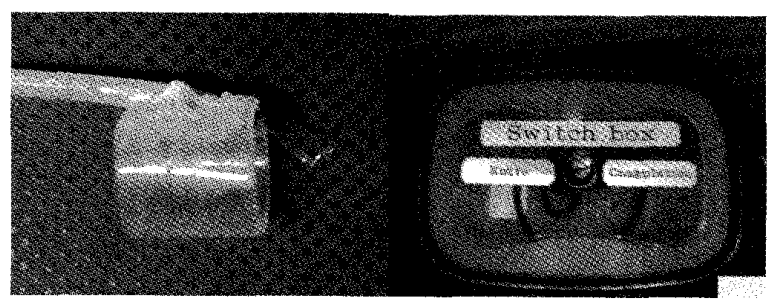

Fig. 15. Coagulation-irrigation hood. 
出現も予想され, 現時点ではこれ以上の発展 はないと考えている。

5) 振動機能付き内視鏡 (Figs. 16,17) (科学研 究費補助金 ; 基盤研究 (C) (課題番号 19590742) を獲得)

I . 着想・背景：携帯電話の着信機能に用い られている振動が追加された髡剃り(ジレッ 卜社製M3パワー) が市販化された時にこのの 振動は生体に安全な振動と考え, 内視鏡治療 の現場へ導入することを着想した。

II. 特許出願：例えば, ESDで切除効率を上 昇させる因子を考えれば, 経験か高周波電源 装置の出力を上昇させることになるが, 後者 は穿孔などのリスクを伴う。この二者のどち らにも属さない第 30 要素として「振動」を提 案し, 新規性, 進歩性いずれもあると考元, 振 動機能付きEAMフードの項でも提示したよ うに二つの出願をした $[11,12]$.

III.デバイス紹介論文：沉用内視鏡の先端部 の被覆カバーなどを剥がし，干渉構造などを 最小限解体してシコー社より供与された世界 最小の振動モー夕を埋め込久熱収縮チューブ などで加工して製作した，文字通り，ブルブ ル振える内視鏡となった(Fig. 16)。振動数可 変装置(Fig. $17 \mathrm{a}$; 振動数可変装置, b ; フット スイッチ) も作成し, 無振動群, 5,000 rpm振動 付加群, 10,000 rpm振動付加群の3群で検討し た. 切除豚胃を用いて同一条件下で18(各6切 片)の仮想病変に対LESDを実施した。10,000 $\mathrm{rpm}$ 振動付加群と無振動群の2群間のみにて有 為差をもって前者が後者に対して $15 \%$ の手技 時間の短緧を認めた。また，振動による画像 の歪みの出現が懸念されたが, ストロボ発光 であるシステム光源の周波数が, 内視鏡本体 の振動数を相殺したと考えられ，歪み，ブレな どはまったく出現しなかった[23].

NV. 臨床応用：完成度も高く, 防水面の課題 が克服されれば, 臨床応用する予定である。

$\mathrm{V}$. 特許申請〜 VII. 商品化の検討：IV段階で 留保.

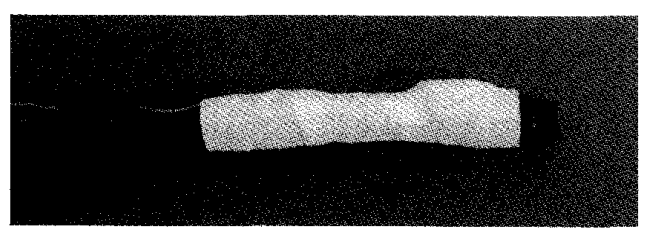

Fig. 16. Vibration endoscope.

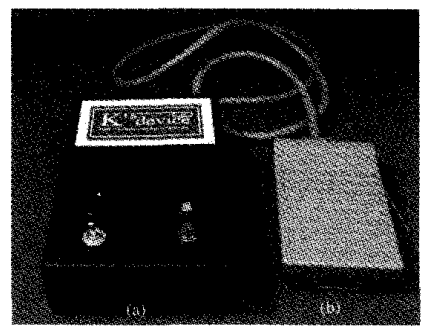

Fig. 17. Variable vibration frequencies are supplied from the device box (a) and foot-switch(b).

6) 内視鏡用ファンデバイス (Fig. 18)

I . 着想・背景：内視鏡に上る切除・切開・剥 離の際には, 電気的焼灼により煙が発生する。 この煙が消化管内に充満すると視野が不良と なり手技の継続が困難となる。通常，このよ うな場合，煙と共に消化管内の空気をすべて 吸引し, 再度新しい空気を入れて, 視野を良好 にする。しかし，このような空気の入れ替え は, 何度も繰り返すことが多く, 手技時間を遷 延させてしまう。そこで, 空気の容量を変え ることなく, 術野周辺のみに送風もしくは換 気することで視野を良好にする新しい二つの デバイスを開発した。送風型 (Fig. 18a) と換気 型(Fig. 18b)である。いずれも, シコー社製の 超マイクロファンモータを用いて製作した。

II. 特許出願:構造上, 特許性を見出せなかった。 III. デバイス紹介論文：無風群, 送風群, 換 気群で, 切除豚胃の仮想病変に対してESD

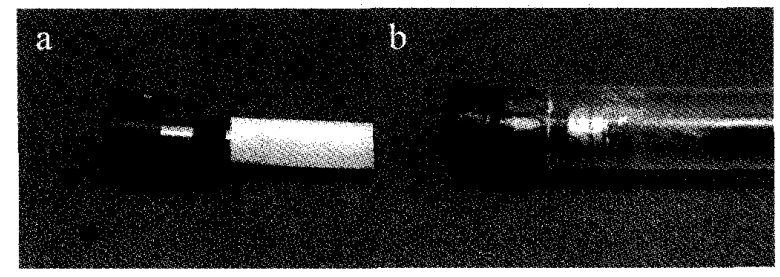

Fig. 18. Endoscopic fan device (a: blowing type, b: ventilation type). 
を各々 3 切片実施した。空気の入れ替えは, $4.33,2.67,1.33$ 回で無風群に対して換気軍が 有意に少なかった[24].

IV. 臨床応用：換気型の効率が良く, 防水面 の課題が克服されれば臨床応用可能である.

$\mathrm{V}$. 特許申請〜VII. 商品化の検討：IV段階で 留保.

4. 内視鏡システムに関する開発研究 ( 2 件)

1）マイクロロボット型自走式大腸内視鏡 (Fig. 19)

I 。着想・背景：ダブルバルーン内視鏡の原 理を応用した自走式大腸内視鏡が開発された が[25]，これ以前に大腸の襞を障害物と見立 て自走する超小型ロボットを着想し，たいへ ん子備的ながら障害物回避型マイクロロボッ 卜を開発した(Fig. 19a)。合わせて専用のマ イコン (Fig. 19b) も制作し, 実際平面上で障害 物回避ロボットとして作動したが，これ以上 の発展を見込めなかった。

II. 特許出願〜VII. 商品化の検討：I 段階で 留保.

VIII. 追加：本開発は当科で開催した第92回日 本消化器病学会総会 $(2006$ 年 4 月) ワーク ショップ「消化器病診断・治療における新しい

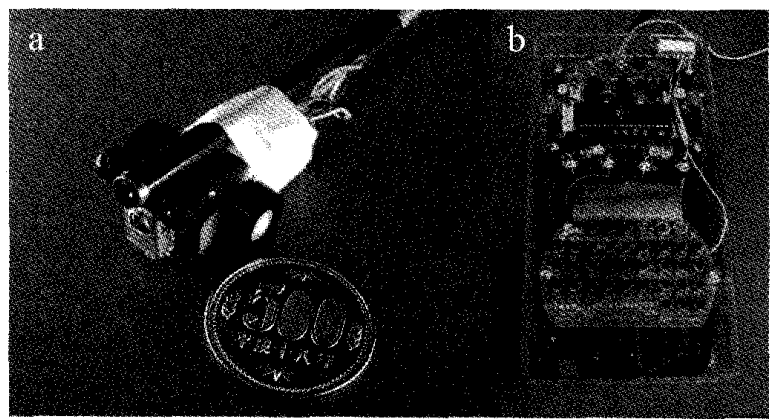

Fig. 19. Micro-robot (a) and exclusive computer (b). deviceの開発と工夫」にて発表した $[26]$.

2) 経口的内視鏡遠隔操作ロボット(北九州產 業学術推進機構；產学連携開発助成金(シー ズ探索助成金)による)

I . 着想・背景：「低侵襲治療」という時代の 流れにより,ESDやNOTES（natural orifice trans- luminal endoscopic surgery) など, 経口的消化管 内視鏡で治療する疾患の適応は拡大の一途で ある、しかしながらここの時代の流れは治療対 象を複雑多岐にし, 精密で長時間を要するもの を増やしつつある。また，右手でハンドル部を 持ちながらアングル操作をし, 左手でファイ バーを持ちながら挿抜と回旋を行う内視鏡操 作には，個人的な癖や習慣が反映されやすく， 習熟に個人差が生じやすい，そこで,内視鏡操 作を操作盤(操作装置, 操作ボックスなど)にて 可能にし,座位にてコントロール可能な経口的 消化管内視鏡ロボットを着想した。

II. 特許出願：上記のコンセプト特許を出願 した $[27,28]$.

III．デバイス紹介論文〜VII，商品化の検討： 現在進行中．学外施設と医工連携で2010年 6 月に試作 1 号機は完成した。

\section{考案}

内視鏡の世界市場は，我が国の3社で $90 \%$ 以上のシェアを占める夏占で他国の追随を許 していない。また，日本消化器内視鏡学会は 会員数 32,000 名を超元, 親学会に当る日本消 化器病学会を係ぐ消化器系学会で最大の規模 を誇って扔り，良くも悪くも内視鏡医療やデ バイス・機器の開発と普及に様々な影響を与 えている。

端的に言えば, 開発·普及の過程が硬直化し て, 柔軟性に久けている。この現状に対する アンチテーゼとして開催したのが, 上述した が, 日本消化器病学会総会の主題演題(ワーク ショップ)である．発表会場の聴衆者席の第 一列にメーカー各社に自社の札を持って待機 して頂き,「これは」と思う演者の研究開発に 札を上げ関心の意を提示して頂くという企画 である (Fig. 20)。演題の採択率は, 3 分の 1 に 満たない学会全体の主題演題中最難関で, 220 名が会場を満たした，当教室が主催した学会 であったので, 実施できた異例の企画であっ た[26]. 


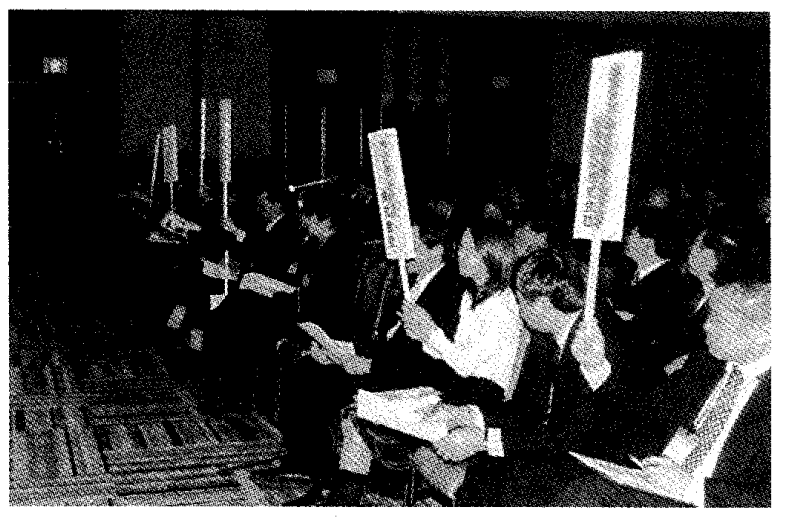

Fig. 20. Society scene.

最近になってこそ, ダブルバルーン小腸内 視鏡やESDの処置具で医師側の個別のアイ ディアが具体化される例が散見されるように なったが, 医工連携や産学連携は看板倒れが 大半で, 医療側の抽象的な必要を採算性の観 点からメーカーが具体化して, 知名度の高い 施設で検証·発表してもらうことで, 新しいデ バイスの普及を狙うというストーリーがメー カーの戦略となって普遍化している。しか し, こうして出現する新しいデバイスや方法 の登場が「医学の進歩」であることを否定はし ないが,「適正な運用」となると，医療として成 熟しているとはとても言えない。新しいデバ イスや方法の研究は, 前向きな手法で正確な 統計処理も行われ, 検討方法としては一流誌 に揭載されても申し分のない方法だが，扱う 変数がそのデバイスの解決課題に設定されて いるので, 結果は自明であることが多い，即 ち, デバイスの性能を立証するような研究で ある。これをもとに運用を開始するので, 性 能と有用性が必ずしもリンクしない場面でも 用いられることになる。二つの日常的な例を あげる，早期消化管癌の診断と治療に関した ものである.

早期消化管癌の診断に用いられる内視鏡 デバイスには, 通常の沉用内視鏡による診断 の他に，超音波内視鏡, IEE (image enhanced endoscopy）などがある。治療前の診断である から, 必要な情報の最重点用件は治療法の決 定にある. 即ち, 内視鏡治療 (大雑把には粘膜
癌) か外科的治療 (大雑把には粘膜下層癌)の 二者択一である。しかしながら, 多数の内視 鏡関連検査を実施しても, 大半の症例の治療 方針は沉用内視鏡による診断が優先して，ま たはこれのみで決定されている．何故なら， 方針の決定には内視鏡医に共通する主観的な バイアス(経験知)がかかるからである。外科 的な手術を実施した症例の術後検討で, 結果 的には外科的な臟器摘出は過侵襲で内視鏡的 に治癒できたものと判明すると誤診とは言わ ないまでも後味が悪いので(この逆は，侵襲の 低い治療が先行したので納得がいく)，アン ダー・ダイアグノーシスになる。胃癌治療ガ イドラインにも用いられている「肉眼的粘膜 癌」という用語には, 微小な粘膜下層浸潤の可 能性は否定できないが, 見た目には粘膜癌で ある，即ち、まずは内視鏡治療をすべきである との判断を導き出す意味合いがある[29]. 他 の新しいデバイスも，この微妙な診断をする には経験を要し, 且つ, 正診率も低くなるの で, 多少異なる診断を出しても沉用内視鏡に よる診断を重視することになる，沉用内視鏡 以外の診断デバイスは, 本来実施しなくても 沉用内視鏡のみで容易に診断できる症例を含 め, 治療前後の画像対比など, 術後の結果に対 する正診率の優劣に重きが置かれているのが 実情である，学会などの発表も，このような デバイスの性能を立証する研究が多数を占め るにもかかわらず，繰り返し聞いていると診 断の必須アイテムのような錯覚を抱くように なっていく，少ない検査で, 最適の結果を出 すことに,インセンティブが与えられないと， この現状に変化を齎すことは困難であろう。 しかしながら,このことに, 余り強いインセン ティブを与えると, 今度はデフレスパイラル になり，研究が萎縮してしまうことになりか ねず，識者は中庸的な知恵を絞り出すべきで ある。

内視鏡治療の適応となる早期消化管癌 (ガ イドライン病変)では, 原疾患の生命予後が問 題となることは，まずない，粘膜癌(食道で 
は, 粘膜固有層癌)であれば, 術前の哚達度診 断に対する保険として病変の最深部と推定 される部位にまずEMRを施行し，遺残があれ ば追加切除か焼灼などを一期的に実施して, 鬼も角, 癌の部位を消失しさえすれば,ほほ確 実に局所治癒できることを経験的な実践知 として持っているが, 一括切除でないと病変 の全体像を評価できないので, ややアカデミ ズムに欠ける．日本消化器内視鏡学会により 唯一行われた早期胃癌のEMRに関する前向 き試験においても, 完全一括切除率 $71.9 \%$ で, 経過観察中に遺残・局所再発を $4 \%$ に認めて いるが, この場合も内視鏡的な局所治療(場合 によって手術)を追加しさえすれば, 局所治癒 を獲得し原病死ゼ口，即ち生命予後に影響を 与えないことを証明している[30].しかしな がら, EMRでは, 一括切除可能な病変に手技 的な限界があって, 胃癌治療ガイドラインで は径 $20 \mathrm{~mm}$ 以内の病変が手技の適応とされて いる.そこで，この問題を解決するために開 発されたのがESDである. 手技の最初に切除 する範囲に切開を入れて, 即ち理論上は必ず 一括切除ができるような処置をしてから剥離 するので, 意図通り完遂できれば病変の大き さに関係なく完全一括切除になる。従って， ESDの長所を最大限活かすために, 安全域を 保って, 外科手術との適応境界に対して上方 拡大を図っていくのは有意義なことだが, 手 技を修得するために，下方拡大するのは，ヘル シンキ宣言の精神などを考慮すれば倫理的問
題に抵触しかねない、幾ら良い方法でも普及 のために，より少ない侵襲で治癒が達成され る患者に施行するのは, 適切ではない。より 低侵襲なEMRで治瘉する小さな早期消化管 癌症例に対して, 大きな病変を持つ任意の患 者に備えて,ESDという過大侵襲をすること には疑問が残る。一括切除という点を除けば, 他の面では優れているEMRの容易さ・安全性 などの特筆すべき低侵襲性を過去のものとす べきではない(Table 2).「完全一括切除」とい う概念に余りに潔癖になりすぎて, 対象疾患 のほぼ完全な局所治癒の獲得と現病死がゼロ であるという大前提を忘れてはならない。

現在, ESDがすべての早期消化管癌の標準 治療との錯覚を持ちかねないようなテーゼの 乱立だが，識者や学会のミスリードのように 思われる，死亡例を含めた深刻な合併症の存 在や先進的でない標準的な施設の現状も十分 に検討して, 柔軟性に富んだ適正な運用基準 を提示するか, より困難と思われるが, 先進 的な施設への選択と集中を試みるべきであ ろう。因みに，当科の関連施設を含めた早期 胃癌 365 症例の検討では, 病変径 $7 \mathrm{~mm}$ でEMR とESDの一括切除率が同一となったので, 10 $\mathrm{mm}$ 未満をEMR, $10 \mathrm{~mm}$ 以上を $\mathrm{ESD}$ 適応の目 安としている $[31]$ 。 また, 食道では, 73症例 99 病変の粘膜固有層癌の検討で44.4\%の低い一 括切除率にも拘らず局所再発は $11.0 \%$ で, こ れらは全例内視鏡的治癒を得ており, 異時性 多発の16.4\%を下回っていた[32]，高率な異

Table 2. EMR vs ESD

\begin{tabular}{lll}
\hline 内視鏡的治療法 & EMR & ESD \\
\hline 1. 一括切除率 $(\%)$ & 71.9 & ほぼ 100 \\
2. 原 病 死 $(\%)$ & 0 & 0 \\
3. 局 所 再 発: 要追加治療 $(\%)$ & 4 & ほほ 0 \\
4. 治療の難易度 (医療スタッフの負担) & 易(軽) & 難 $($ 重) \\
5. 治 療 時 間 & 短 & 長 \\
6. 合併症の頻度 & 極少 & 少 \\
7. 保 険 点数 & 4,970 & 11,000 (胃), 17,000 (食道) \\
\hline
\end{tabular}

但し, ガイドライン内病変である1） $20 \mathrm{~mm}$ 以内, 2) ul (-), 3) 粘膜癌の 3 条件を満たす場合に限る 
時性多発により複数回の内視鏡治療を避けら れない食道癌では, 局所治瘉の得られるEMR で臨床的満足度は高く, 敢えて胃よりリスク の高い食道でのESDを施行するメリットは少 ないと考えられた。但し, 粘膜固有層癌との 限定付きである.

ESDは開発者らの布教活動とメーカーの拡 大戦略が幸いして, 平均的な技量の底上げも なされつつあるし，筆者自ら製品化されたデ バイスも提供しているので, 䲅立てた言説を 弄するのは如何か, との批評を頂きそうたが, 実は,このESDの出現を境に, 治療法や穖器の 開発において「内視鏡的治癒」から「内視鏡的 治癒の質」へと焦点の転換が起きたことに注 視している。ここに, 低侵襲治療の本質的な 問題がある．内視鏡的に治癒できるのは当然 で, 如何に治療の質の问上を図るかに焦点が 移項したのである。毛もも，治癒が最終目 的であっても，鋳型に入れて同じ結果を出せ る様な機械的な作業でない侵襲的医療行為 にリスクは当然伴うところに, 今度は治療の 過程の明確化や患者の手術痕を小さくするこ となどを目的とする「質」を重視した低侵襲治 療へ「時代の要求」が変化したのである。しか も,この低侵襲性を患者へ提供するのに, 医療 側の負担は逆説的に増大寸る。さらに, 治癒 が最終到達点である時代は, 多少の合併症や 様々な価值観の無視は許容されても，質を目 指す時に伴う合併症や経費·侵襲には, 個人的 価值観を勘酌しなければならないし，倫理的 な妥当性も重みを増してくると思われる。

実際, 究極の低侵襲治療として注目されてい るNOTES (natural orifice transluminal endoscopic surgery）をどのような臨床的状況で実現するか は難しい，まさしく，ウイスキーの瓶の中で 帆船を組み立てるような作業であり，術者に 高度な技量を要求し，専用デバイスの開発に
鎬を削るたいへん刺激的な治療である。経口 的に胃壁を介するか, 経直腸的,または経塍的 なルートを介して腹腔内臟器の手術を完遂さ せ,体表には一切の傷を残さないのが,コンセ プトである．美容外科との見解があっても可 笑しくないが, 既にNOTESによる虫垂切除術 や胆囊摘出術は臨床応用されている $[33,34]$. 右下腹部に従来通りの虫垂切除術痕があって も，差し支えないと思うのは筆者だけではな いと考えるし, NOTESに対して術者が背負う リスクやルートとなった傷害臓器の長期予後 の問題, 技術研修, 設備投資を考えると保険診 療にすべきか否か,どのような疾患を積極的 な対象疾患とするかは十分な検討を要する.

以上のように，技術的に可能となったこと と臨床的な適切さとは，必ずしもパラレルで はない。一旦, 新技術として臨床の場に出現 してしまうと, 様々な思惑が交錯して, 適切な 運用という中庸にはなかなか落ち着かない. そこで,「臨床の場」へ登場させる際の入口戦 略として,独自のフローチャートと，これに基 づく経験を述べた。これまで, 研究者一個人 として, 自分の目で臨床応用された現場を目 撃できることを目指して研究をしてきたが， ここをあまりに性急に進めると思わぬ事故に 遭遇する可能性は否めず, また研究者の本能 として強引に臨床応用してしまいかねない 人間の弱さも存するとも考光，自身に対する 指針·安全弁として作成したのが,このフロー チャートである。また,これらの検討から, 豚 などの動物を用いた箺験系での基礎的な学問 的な体系の整備の必要も感し，「実験内視鏡学 (experimental endoscopology)」の確立も別途提 唱した $[35,36]$. いずれにせよ，医学の進歩が 最適の医療として実践されることが, 患者に とって第一である。 


\section{引用 文 献}

1. 久米恵一郎 (2006): 内視鏡用洗浄機能付き透明フード，特許第3790866号

2. Kume K, Yoshikawa I \& Otsuki M (2003): Endoscopic treatment of upper GI hemorrhage with a novel irrigating hood attached to the endoscope. Gastrointest Endosc 57: 732-735

3. Kume K, Yamasaki M, Yamasaki T, Yoshikawa I \& Otsuki M (2004): Endoscopic hemostasis treatment under irrigation for upper-GI hemorrhage: A comparison of one third and total circumference transparent end hoods. Gastrointest Endosc 59: 712-716

4. Kume K, Yamasaki M, Kubo K, Mitsuoka H, Oto T, Matsuhashi T, Yamasaki T, Yoshikawa I \& Otsuki M (2004): EMR of upper GI lesions when using a novel soft, irrigation, prelooped hood. Gastrointest Endose 60: 124-128

5. 岸孝浩, オリンパス株式会社 (2003)：内視鏡用外付けチャンネル．特願2003-371905号

6. Kume K, Yamasaki M, Kanda K, Hirakoba M, Matsuhashi T, Santo N, Syukuwa K, Yoshikawa I \& Otsuki M (2006): Grasping forceps-assisted endoscopic mucosal resection of early gastric cancer with a novel 2-channel prelooped hood. Gastrointest Endosc 64: 108-112

7. Kume K, Yamasaki M, Tashiro M et al (2008): Endoscopic mucosal resection for early gastric cancer: comparison of two modification of the cap method. Endoscopy 40: 280-283

8. Kume K, Yamasaki M, Yoshikawa I \& Otsuki M (2007): Endoscopic aspiration mucosectomy and closure assisted by outside CCD camera. Endoscopy 39: E214-E215

9. 久米恵一郎 (2005)：マルチカメラを導入した内視鏡. 特願2005-236132号

10. Kume K, Yamasaki M, Yoshikawa I \& Otsuki M (2007): Multi-camera system of the endoscopy: endoscopic mucosal resection for large gastric lesion using a novel 1-channel camera-hood. Endoscopy 39: E186-E187

11. 久米恵一郎, 北九州TLO (2006)：振動機能付き内視鏡. 特願2006-236656号

12. 久米恵一郎, 北九州TLO (2007): 内視鏡, 内視鏡フード, 処置用チューブ及び内視鏡キャップ. 特願2007-204642号

13. Kume K (2009): Endoscopic aspiration mucosectomy using a novel vibration hood. Endoscopy 41: E296-E298

14. 久米恵一郎 (2008): 発明の名称：内視鏡用フードナイフ．特許第4061594号

15. Kume K, Yamasaki M, Kanda K, Yoshikawa I \& Otsuki M (2005): Endoscopic submucosal dissection using a novel irrigation hood-knife. Endoscopy 37: 1030-1031

16. Kume K, Yamasaki M, Yoshikawa I \& Otsuki M (2007): Grasping-forceps-assisted endoscopic submucosal dissection using a novel irrigation cap-knife for large superficial early gastric cancer. Endoscopy 39: 566-569

17. Yonezawa J, Kaise M, Sumiyama K, Goda K, Arakawa H \& Tajiri H (2006): A novel double-channel therapeutic endoscope ("R-scope") facilitates endoscopic submucosal dissection of superficial gastric neoplasms. Endoscopy 38: 1011-1015

18. Kume K, Yamasaki M, Kanda K, Yoshikawa I \& Otsuki M (2007): Endoscopic submucosal dissection using a novel irrigation wiper knife. Endoscopy 39: E144

19. 山崎雅弘, 久米恵一郎, 学校法人産業医科大学 $(2005)$ : 高粘調物質を用いた内視鏡的粘膜剥離 術及びそのシステム，特願2005-300903号 
20. Yamasaki M, Kume K, Kanda K, Yoshikawa I \& Otsuki M (2005): A new method of endoscopic submucosal dissection using submucosalinjection of jelly. Endoscopy $37: 1156-1157$

21. Yamasaki M, Kume K, Yoshikawa I \& Otsuki M (2006): A novel method of endoscopic submucosal dissection with blunt abrasion by submucosal injection of sodium carboxymethylcellulose: an animal preliminary study. Gastrointest Endosc 64: 958-965

22. Kume K, Yamasaki M, Yoshikawa I \& Otsuki M (2006): New device to perform coagulation and irrigation simultaneously during endoscopic submucosal dissection using an insulation-tipped electrosurgical knife. Dig Endosc 18: 218-220

23. Kume K (2010): Endoscopic submucosal dissection using a novel vibration endoscopy. HepatoGastroenterology 57: 224-227

24. Kume K (2009): Endoscopic therapy using novel fan devices. Endoscopy 41: E236-E237

25. Vucelic B, Rex D, Pulanic R, Pfefer J, Hrstic I, Levin B, Halpern Z \& Arber N (2006): The Aer-OScope: Proof of concept of a pneumatic, skill-independent, self-propelling, self-navigating colonoscope. Gastroenterology 130: 672-677

26. 久米恵一郎, 山本博徳 (2006): ワークショップ「消化器病診断・治療における新しいdeviceの開 発と工夫」. 日本消化器病学会雑誌 103 suppl 1: A129-A133

27. 久米恵一郎, 学校法人産業医科大学 (2009): 内視鏡システム. 特願 2009-129643号

28. 久米恵一郎, 学校法人産業医科大学 $(2010)$ ：内視鏡システム. 特願2010-107658号

29. 日本胃癌学会 (2004): 胃癌治療ガイドライン医師用. 第2 版. 日本胃癌学会, 東京 pp 8-9

30. Ida K, Nakazawa S, Yoshino J et al (2004): Multicentre collaborative prospective study of endoscopic treatment of early gastric cancer. Dig Endosc 16: 295-302

31. Watanabe T, Kume K, Tai Y, Shibata M, Kubo H, Ejiri Y \& Otsuki M (2010): Gastric mucosal cancer smaller than $7 \mathrm{~mm}$ can be treated with conventional endoscopic mucosal resection as effectively as with endoscopic submucosal dissection. Hepato-Gastroenterology 57: 668-673

32. Kume K (2009): The local recurrence and the metachronous cancer after EMR for early esophageal cancer confined within the lamina propria mucosae. Hepato-Gastroenterology 56: 699-702

33. Palanivelu C, Rajan PS, Rangarajan M, Parthasarathi R, Senthilnathan P \& Prasad M (2008): Transvaginal endoscopic appendectomy in humans: a unique approach to NNTES: world's first report. Surg Endosc 22: 1343-1347

34. Horgan S, Cullen JP, Talamini MA et al (2009): Natural orifice surgery: initial clinical experience. Surg Endosc 23: 1512-1518

35. Kume K (2010): The suggestion of a new general idea called "experimental endoscopology". J Interv Gastroenterol (in press)

36. Kume K (2009): EMR and ESD for early gastric cancer: current and original devices. World J Gastrointest Endosc 1: 21-31 


\section{New Devices for Gastrointestinal Endoscopy}

\section{Keiichiro Kume}

The Third Department of Internal Medicine, University of Occupational and Environmental Health, Japan, School of Medicine, Kitakyushu, Japan

Abstract : Advances in endoscopic therapeutic techniques and procedures are reducing invasiveness, thereby lightening the burden on the patient. At the same time, they are increasing the burden on those who administer the endoscopic therapy to ensure successful outcomes. As we enter the era of minimally invasive therapy, a clear need has arisen for the formulation of a basic strategy for the types of therapeutic methods and devices that can and should be provided for use in clinical medicine. Therefore, I introduced the perspective of my own experience by my original criterion.

Key words : new device, gastrointestinal endoscopy, minimally invasive surgery.

J UOEH $32(4): 349-365(2010)$ 